\title{
Effect of Bacterium on Phytoremediation of Scirpus mucronatus Planted in Lead-Contaminated Soil
}

\author{
A. Yavar ${ }^{\mathrm{a}}$, S. Sarmani ${ }^{\mathrm{b}}$, A. $\operatorname{Hamzah}^{\mathrm{c}}$, K. S. Khoo ${ }^{\mathrm{a}}$ \\ ${ }^{a}$ School of Applied Physics, Faculty of Science and Technology, The National University of Malaysia (UKM), \\ 43600 Bangi, Selangor, Malaysia \\ ${ }^{b}$ School of Chemical Sciences \& Food Technology, Faculty of Science and Technology, The National University \\ of Malaysia (UKM), 43600 Bangi, Selangor, Malaysia \\ ${ }^{c}$ School of Biosciences and Biotechnology, Faculty of Science and Technology, The National University of \\ Malaysia (UKM), 43600 Bangi, Selangor, Malaysia
}

\begin{abstract}
Realizing the mechanisms of capability of phytoremediation of a plant is vital when deciding what type of bacteria to utilize with a plant in a given contaminated situation. Effect of two types of bacterium namely Brevundimonas diminuta and Alcaligenes faecalis were inspected on Scripus mucronatus grown in $100 \mathrm{ppm} P b$ contaminated soil. The Scripus mucronatus cut to five identical pieces and elemental concentrations of them were determined using inductively coupled plasma optical emission spectrometry (ICP-OES) technique on day 1 and day 42 after enrichment by bacterium. To evaluate statistical differences in the elemental concentration between samples of bacteria 5, bacteria 60 and control, the one-way ANOVA test was examined. Performance of one-way ANOVA test were demonstrated which there were significant statistical differences in all elemental concentrations between samples of bacteria 5, bacteria 60 and control ( $p>0.05)$. On other hand, Pearson's correlation test was performed to find correlation elemental concentrations between samples of bacteria 5 and bacteria 60 versus those in sample of control. There were significant correlations between the all elements $(R>0.3)$ except Be, Mo and $\mathrm{Zn}$ in sample of bacteria 5 versus control; as well Sb in sample of bacteria 60 . The results were shown which these two bacterium were benefit for increasing of heavy metal uptake from contaminated soil.
\end{abstract}

Keywords: Lead contamination, ICP-OES, Scripus mucronatus, Phytoremediation, Brevundimonas diminuta and Alcaligenes faecalisin bacterium.

\section{INTRODUCTION}

Heavy metals are the most widespread contaminants in the environment, and one of the most common of these is lead, with industries like paint and battery manufacturers and lead smelting plants being the main sources of lead production. In addition, it has been recognized that lead operates as an accumulated toxin, and inorganic lead acts as an inhibitor enzyme that is harmful to the nervous system. The most toxic form is ionic lead, which when it spreads to the environment, can be absorbed by the body through drinking water, food, or the air $[1,2]$. The general spread of toxic elements in the environment poses a serious problem for human health, and the U.S. Environmental Protection Agency has designated silver (Ag), arsenic (As), barium (Ba), beryllium (Be), cadmium $(\mathrm{Cd})$, chromium $(\mathrm{Cr})$, copper $(\mathrm{Cu})$, mercury $(\mathrm{Hg})$, manganese $(\mathrm{Mn})$, molybdenum (Mo), nickel ( $\mathrm{Ni})$, lead $(\mathrm{Pb})$, antimony $(\mathrm{Sb})$, selenium $(\mathrm{Se})$, and zinc $(\mathrm{Zn})$ as potentially toxic elements [3].

Phytoremediation is a procedure that uses plants to decrease and/or remove contaminants from the environment. It is a better option as a recovery technique than other methods because it is cost effective and environmentally friendly. Globally, soil contamination is a vital environmental problem affecting human health, and remediation technologies are necessary to resolve the problem of lead-contaminated soil [4, 5]. Hyperaccumulator plants have the ability to take up large amounts of toxic metals in contaminated soils. Adam and Duncan [6] have shown that grasses are good hyper-accumulator plants for contaminated-soil remediation due to their fibrous root systems that have an extensive surface area for microbial colonization. The fibrous root system forms a continuous dense rhizosphere, which provides the ideal conditions for phytoremediation.

In this study, we utilized Scirpus mucronatus, a monocot weed in the Cyperaceae family. This plant is known by the general name of ricefield bulrush, as well as by its local name in Malaysia, 'rumput kerecut'. It is a perennial herb growing from a short, hard rhizome in shallow water and moist and wet terrestrial habitats. The triangular stems grow in thick clumps up to a meter tall with leaves that wrap around the base of the stem in sheaths, although they often do not have blades [7, 8].

To obtain the full potential of a phytoremediation technique, it is essential that the plant grow as large as possible in order to take up the various environmental contaminants. One way to achieve this is to employ plant growth-promoting bacteria to assist the growth of the phytoremediation plant [8-10]. The aim of this study 
was to assess the effect of two bacterium, Brevundimonas diminuta (bacteria 5) and Alcaligenes faecalis (bacteria 60), on the phytoremediation of lead-contaminated soil planted with Scirpus mucronatus.

\section{EXPERIMENTAL ProcedURES}

The Scirpus mucronatus was propagated from seeds in a greenhouse at the Universiti Kebangsaan Malaysia using garden soil in polyethylene crates $(40 \mathrm{~cm} \times 58 \mathrm{~cm} \times 30 \mathrm{~cm})$. After 5 weeks, a lead solution (100 ppm) was added to the crates with no bacteria (control), inoculants of bacteria 5 , or bacteria 60 . Samples of the Scirpus mucronatus were prepared 1 and 42 days after the addition of the lead solution and the bacteria to the soil. The samples were first rinsed in ultra pure water (18.2 M $\Omega$ quality, model: LPTA/PB/7/1 - Maxima Ultra Pure Water, ELGA company, Italy) to remove dust-borne contamination, after which each plant was cut crosswise from root to shoot into 5 sections of equal length before drying in an oven at $90{ }^{\circ} \mathrm{C}$ for 2 days. Subsequently, $200 \mathrm{mg}$ samples were placed in heat-resistant tubes, and $5 \mathrm{~mL} 69 \% \mathrm{HNO} 3$ and $3 \mathrm{~mL} \mathrm{H} 2 \mathrm{O} 2$ were added; the samples were then heated in a microwave (Milestone Start D Microwave Digestion System, VAC$1000)$ with $300(\mathrm{~W})$ energy, $20-120\left({ }^{\circ} \mathrm{C}\right)$ temperature, for $55 \mathrm{~min}$. Microwave digestion was used instead of classical methods because of its shorter time, less acid consumption, and ability to retain volatile compounds in the solutions. The residues were filtered by using a $0.45 \mu \mathrm{m}$ Whitman filter paper. Finally, the digested samples were diluted to $50 \mathrm{~mL}$ with ultra pure water, and a multi-element analysis was conducted on each sample by inductively coupled plasma optical emission spectrometry (ICP-OES). ICP-OES is an analytical method utilized for elemental determinations that has the benefit of being able to analyse for multiple elements simultaneously and to do so with high precision and sensitivity. This study used the PerkinElmer Elan 7300 DV ICP-OES (USA). After calibrating the instrument by using standard solution derived from commercial materials, the system was optimized based on the recommendation of the manufacturer.

Statistical analyses were performed with IBM SPSS software version 22. A one-way ANOVA with the significance level set at $95 \%$ was employed to identify the factors influencing $\mathrm{As}, \mathrm{Be}, \mathrm{Cd}, \mathrm{Cu}, \mathrm{Mn}, \mathrm{Mo}, \mathrm{Ni}, \mathrm{Pb}$, $\mathrm{Sb}, \mathrm{Se}$ and $\mathrm{Zn}$ concentrations in our samples. P-values $<0.05$ were considered no statistically significant for all tests. Pearson's correlation test was performed to examine the correlation between elemental concentrations in bacteria 5 and bacteria 60 versus those in control sample [11].

\section{RESULTS AND DISCUSSION}

Three sample treatments were utilized in this study. Two of the treatments enriched the leadcontaminated soil with bacteria 5 or bacteria 60 , and the third treatment was growth without the addition of bacteria (control). Fig. 1 to Fig. 11 show the concentrations of the toxic elements $\mathrm{As}, \mathrm{Be}, \mathrm{Cd}, \mathrm{Cu}, \mathrm{Mn}, \mathrm{Mo}, \mathrm{Ni}$, $\mathrm{Pb}, \mathrm{Sb}, \mathrm{Se}$, and $\mathrm{Zn}$, respectively, in each of the 5 plant sections (root to shoot) of Scirpus mucronatus for the 3 treatments. The control samples were used to assess the effects of bacteria 5 and bacteria 60 on the phytoremediation capacity of the Scirpus mucronatus. The concentrations of the all elements in the bacteria 5, bacteria 60 , and control samples were higher after 42 days rather than those on first day, as the most increasing was shown for $\mathrm{Mn}$, and $\mathrm{Pb}$. However variation of $\mathrm{Be}, \mathrm{Cu}, \mathrm{Mo}, \mathrm{Ni}, \mathrm{Sb}$, and Se concentrations on day 1 and day 42 were trifling. It may be caused by internal detoxification mechanism of Scirpus mucronatus. To protect themselves from metal poisoning, plants must have developed a mechanism by which the heavy metal entering the cytosol of the cell, is either immediately excluded or complexed and inactivated, thus preventing the metal from inactivating catalytically active or structural proteins, presumably by adapting mechanism that may also be involved in the general homeostasis of essential mineral ions, and tolerate them. Such plants are resistant to certain metal ions suggesting their potential use for cleaning of contaminated soil [12]. Further, the chemical properties of a small number of pollutant trace elements allow the use of the technology of phytovolatilization. Instead of accumulating inside the plant, the trace element is enzymatically transformed into a less toxic, volatile compound and is subsequently released into the atmosphere [13]. Moreover, it may be due to interactive effect of elements in Scirpus mucronatus. Overall, the interaction at root level among some transition elements could be antagonistic, synergistic or multiplicative. Beckett and Davis [14] found that in barely, the toxic effect of $\mathrm{Cu}$ and $\mathrm{Zn}$ were antagonistic when the tissue concentration of these heavy metals surpassed a critical concentration. On the other hand, in vegetables grown in pots, high concentration of $\mathrm{Zn}$ in the soil solution was synergistic for $\mathrm{Cd}$ uptake. $\mathrm{Ni}$ combined with $\mathrm{Cd}, \mathrm{Mn}$, and $\mathrm{Zn}$, presented a multiplicative effect in the reduction of wheat root growth. It is clear that the presence of $\mathrm{Zn}$ in the growing environment reduced the $\mathrm{Ni}$ toxicity to the alfalfa plants [15].

Table 1 presents mean and range of elemental concentrations in this study. To evaluate the statistical differences in the elemental concentrations between samples of bacteria 5, bacteria 60 and control, the one-way ANOVA test was used [11]. The p-value of elemental concentrations between samples of bacteria 5, bacteria 60 

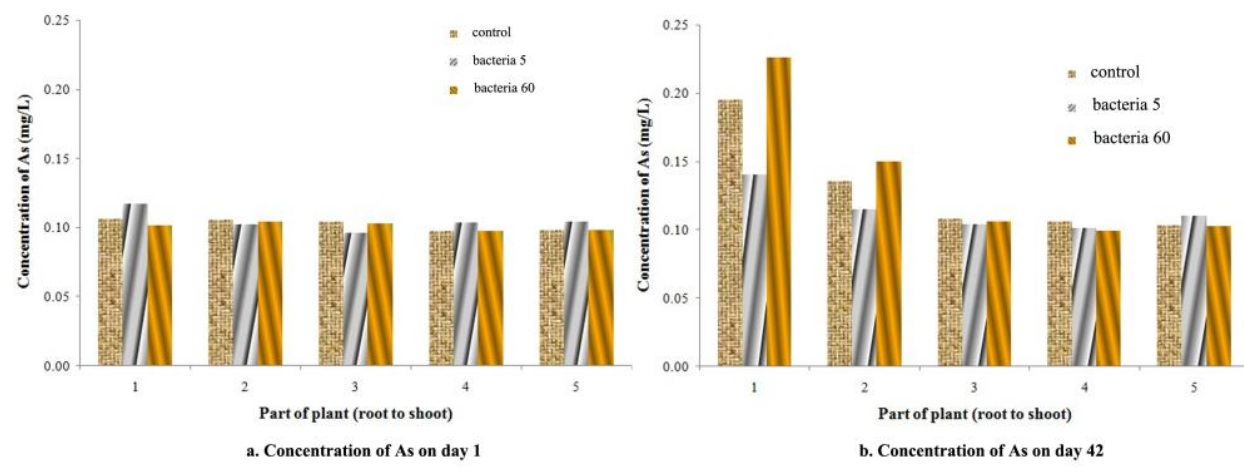

Fig. 1 Concentration of As in 5 identical parts of plant sample (Scirpus mucronatus) after 1 and 42 days of exposure by bacterial inoculums namely Brevundimonas diminuta (bacteria 5) and Alcaligenes faecalis (bacteria 60) in Pb contaminated soil, as well control sample (Control).
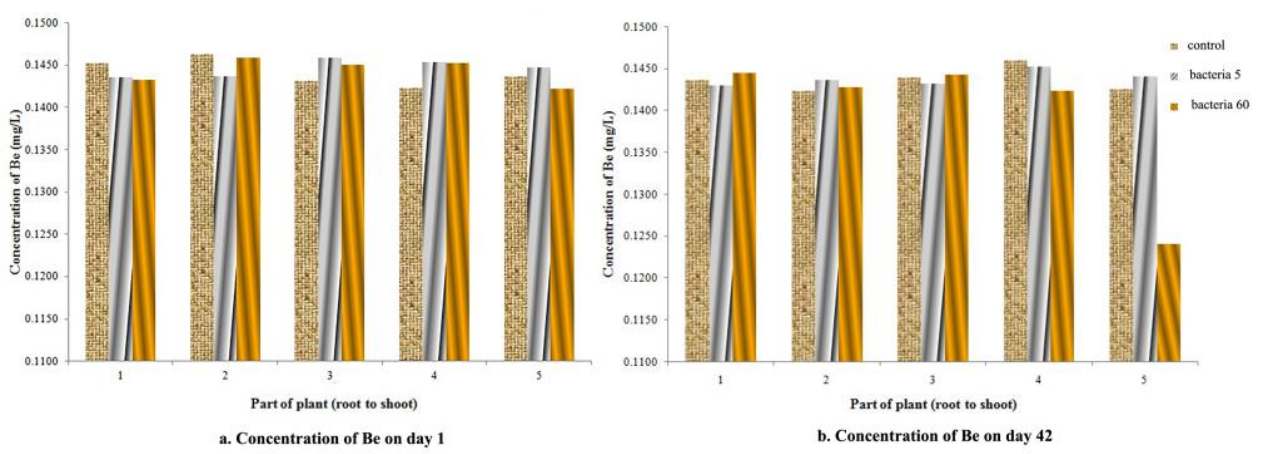
Fig. 2 Concentration of Be in 5 identical parts of plant sample (Scirpus mucronatus) after 1 and 42 days of exposure by bacterial inoculums namely Brevundimonas
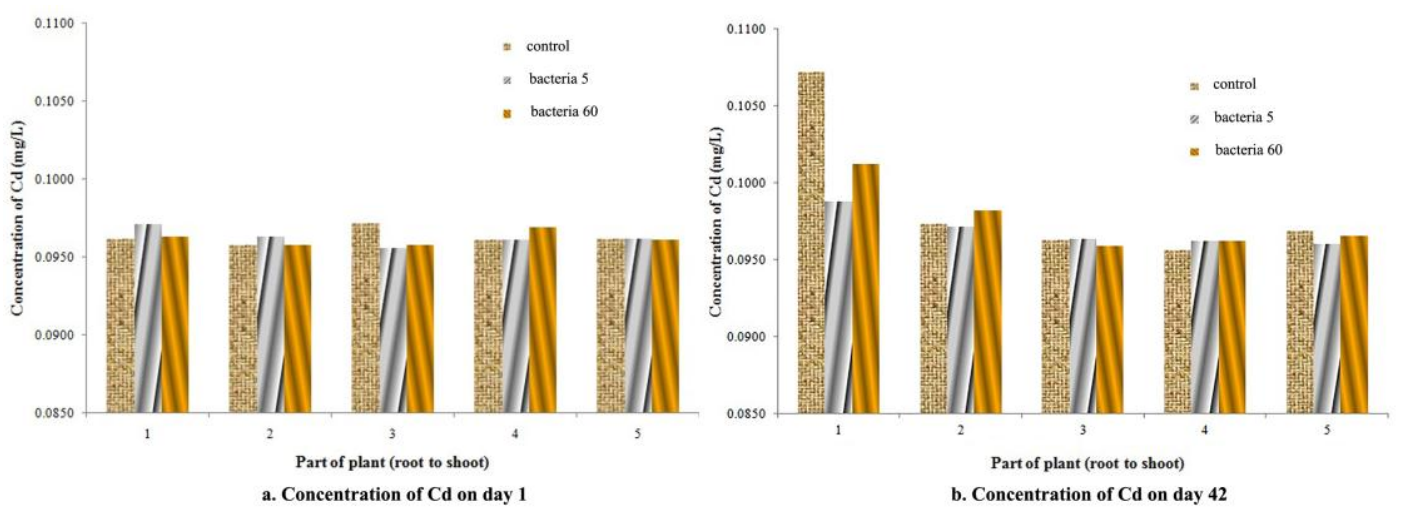

Fig. 3 Concentration of $\mathrm{Cd}$ in 5 identical parts of plant sample (Scirpus mucronatus) after 1 and $\mathbf{4 2}$ days of exposure by bacterial inoculums namely Brevundimonas diminuta (bacteria 5) and Alcaligenes faecalis (bacteria 60) in Pb contaminated soil, as well control sample (Control).
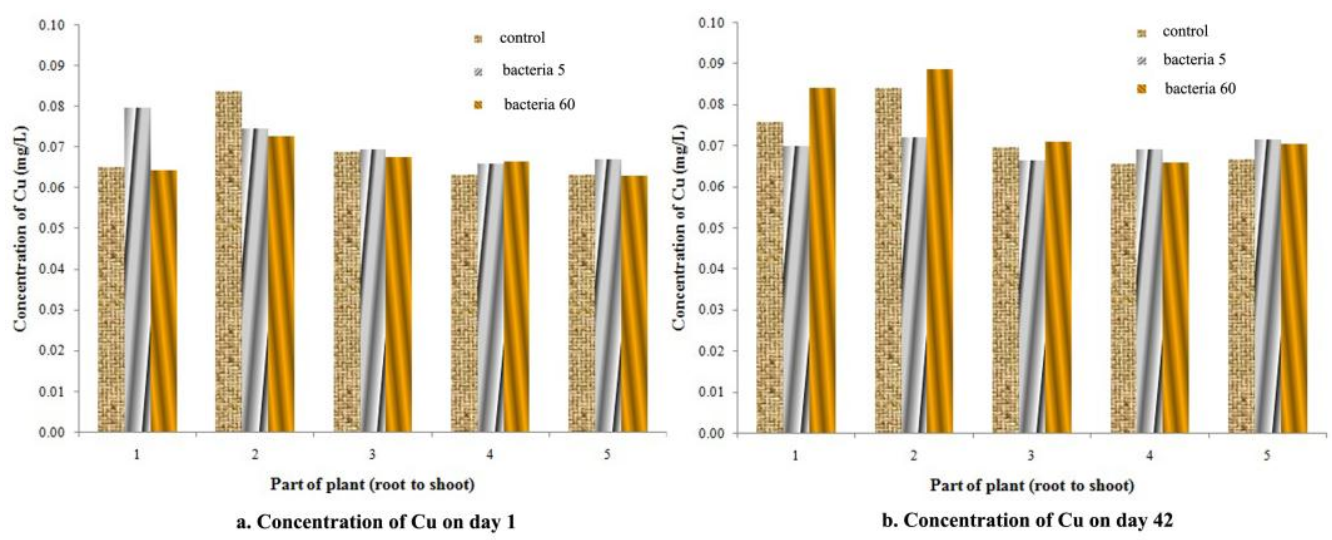

Fig. 4 Concentration of $\mathrm{Cu}$ in 5 identical parts of plant sample (Scirpus mucronatus) after 1 and 42 days of exposure by bacterial inoculums namely Brevundimonas diminuta (bacteria 5) and Alcaligenes faecalis (bacteria 60) in Pb contaminated soil, as well control sample (Control). 

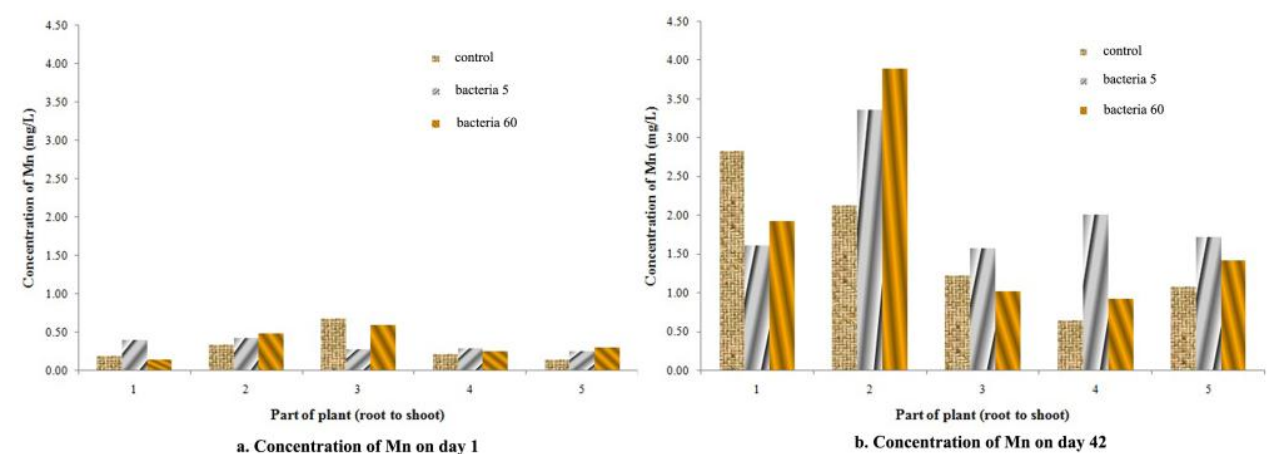

Fig. 5 Concentration of $\mathrm{Mn}$ in 5 identical parts of plant sample (Scirpus mucronatus) after 1 and 42 days of exposure by bacterial inoculums namely Brevundimonas diminuta (bacteria 5) and Alcaligenes faecalis (bacteria 60) in Pb contaminated soil, as well control sample (Control).

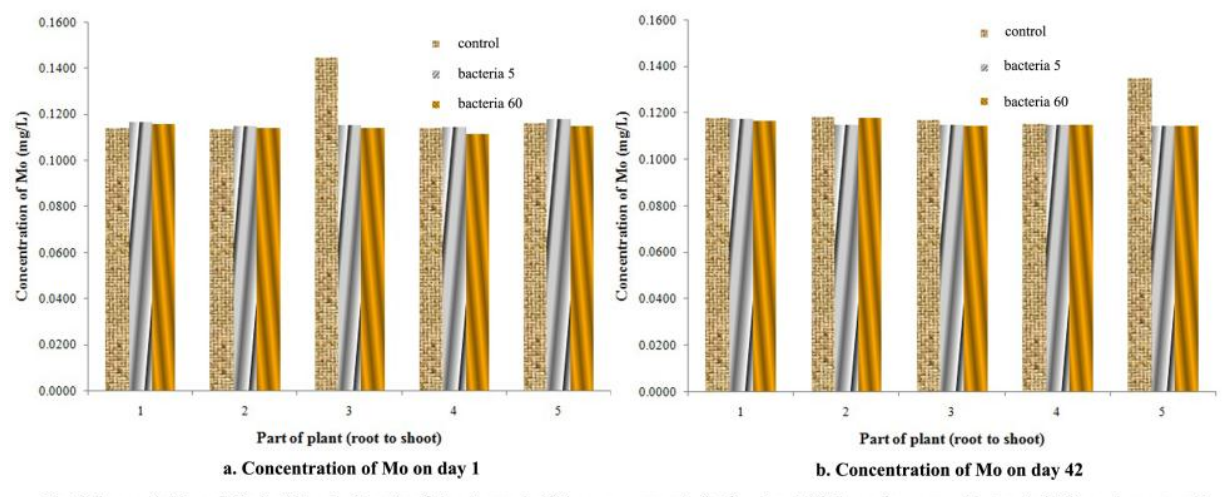

Fig. 6 Concentration of Mo in 5 identical parts of plant sample (Scirpus mucronatus) after 1 and 42 days of exposure by bacterial inoculums namely Brevundimonas diminuta (bacteria 5) and Alcaligenes faecalis (bacteria 60) in Pb contaminated soil, as well control sample (Control).

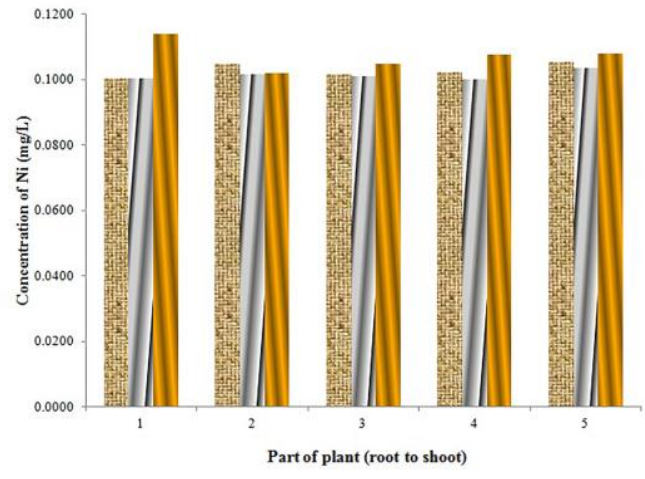

a. Concentration of $\mathrm{Ni}$ on day 1

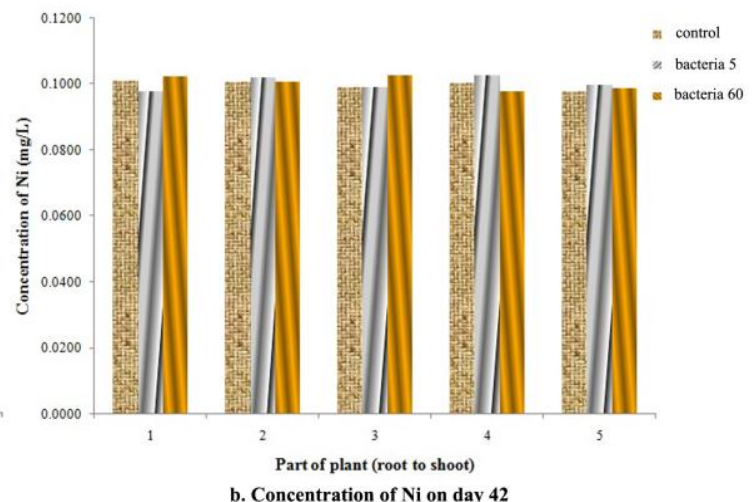

Fig. 7 Concentration of $\mathrm{Ni}$ in 5 identical parts of plant sample (Scirpus mucronatus) after 1 and 42 days of exposure by bacterial inoculums namely Brevundimonas diminuta (bacteria 5) and Alcaligenes faecalis (bacteria 60) in Pb contaminated soil, as well control sample (Control).
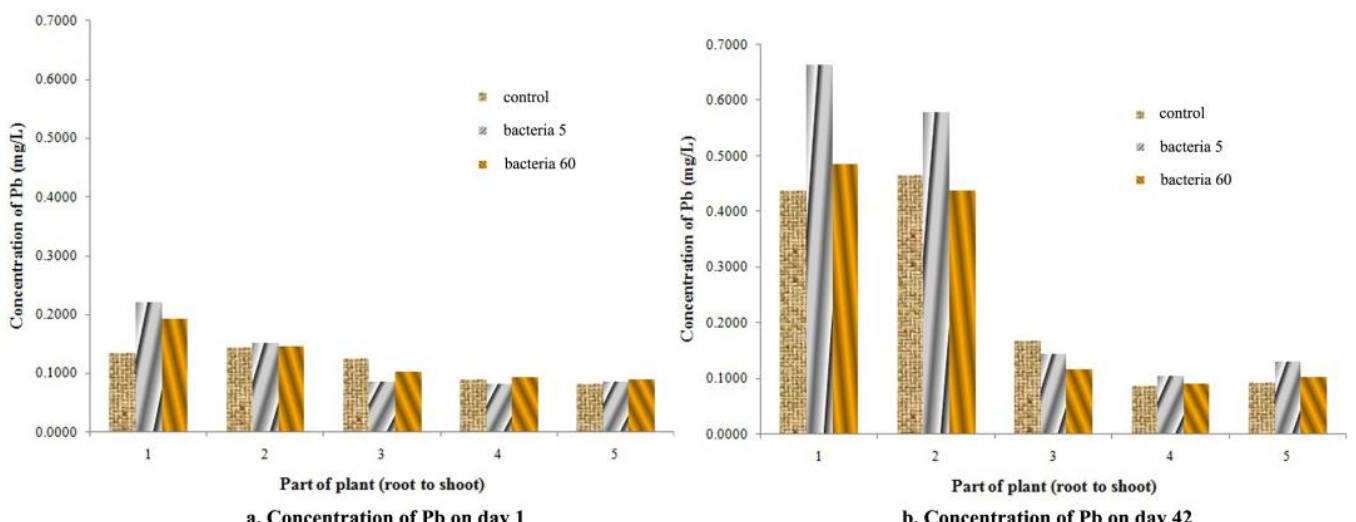

a. Concentration of $\mathrm{Pb}$ on day 1

b. Concentration of $\mathrm{Pb}$ on day 42

Fig. 8 Concentration of $\mathrm{Pb}$ in 5 identical parts of plant sample (Scirpus mucronatus) after 1 and 42 days of exposure by bacterial inoculums namely Brevundimonas diminuta (bacteria 5) and Alcaligenes faecalis (bacteria 60) in Pb contaminated soil, as well control sample (Control). 

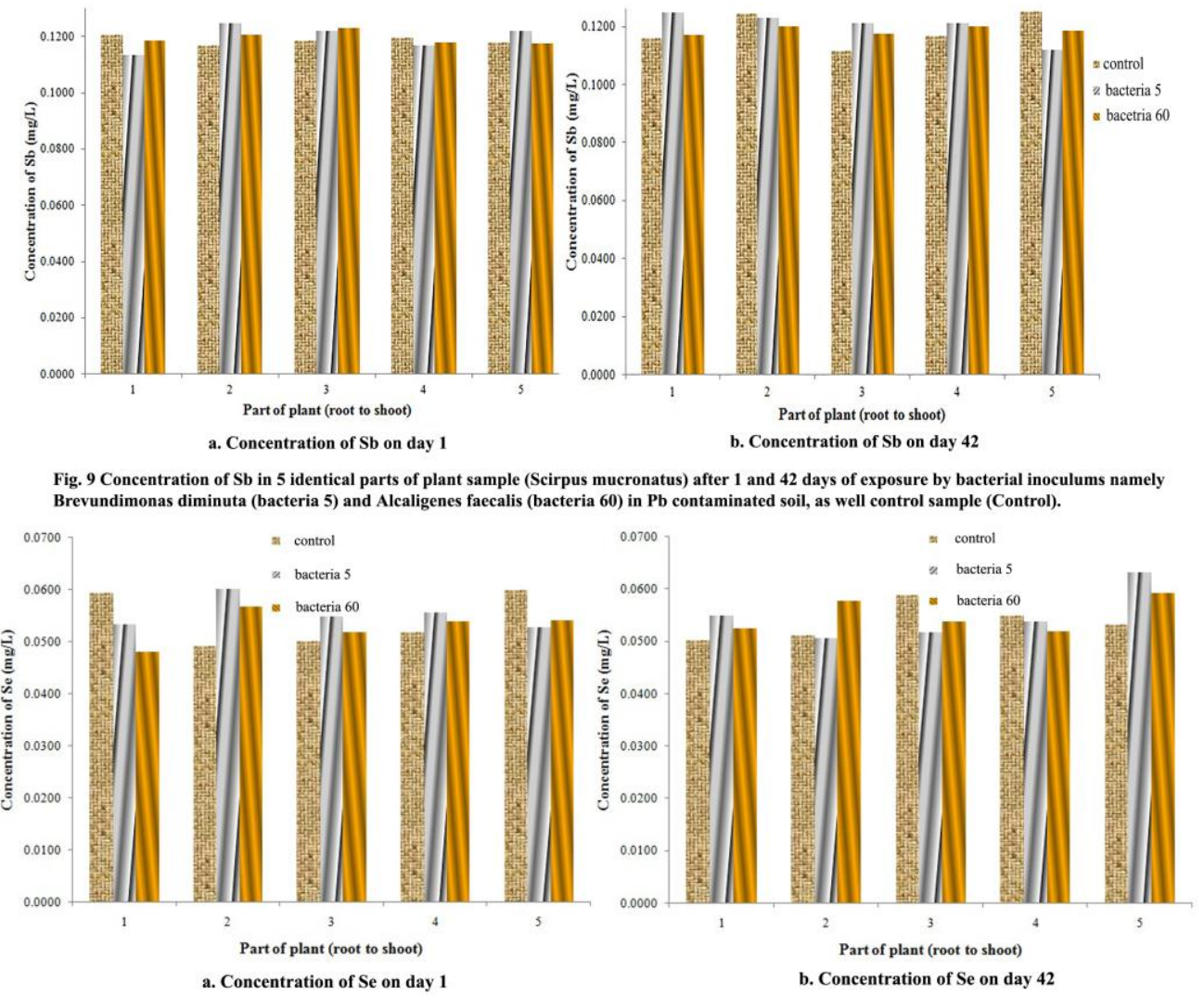

Fig. 10 Concentration of Se in 5 identical parts of plant sample (Scirpus mucronatus) after 1 and 42 days of exposure by bacterial inoculums namely Brevundimonas diminuta (bacteria 5) and Alcaligenes faecalis (bacteria 60) in Pb contaminated soil, as well control sample (Control).

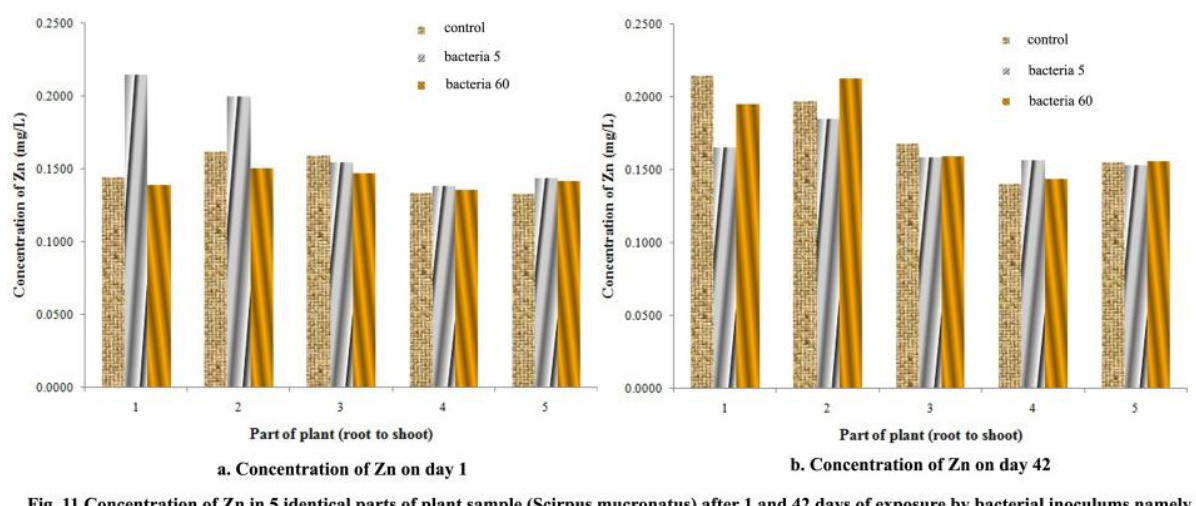

Brevundimonas diminuta (bacteria 5) and Alcaligenes faecalis (bacteria 60) in Pb contaminated soil, as well control sample (Control).

and control has shown in Table 1 which results were demonstrated there were significant statistical differences in all elemental concentrations between samples of bacteria 5, bacteria 60 and control ( $>>0.05)$. To the best of our knowledge, there have been no studies describing the relationship elemental concentrations between samples of bacteria 5 and bacteria 60 versus those of control yet. Hence, Pearson's correlation test was performed to find correlation elemental concentrations between samples of bacteria 5 and bacteria 60 versus those in sample of control. Fig. 12 and Fig. 13 exhibit Pearson's correlation coefficient (R) and regressions between elemental concentrations in bacteria 5 and bacteria 60 versus control. There were significant correlations between the all elements $(\mathrm{R}>0.3)$ except $\mathrm{Be}$, Mo and $\mathrm{Zn}$ in sample of bacteria 5 versus control; also $\mathrm{Sb}$ in sample of bacteria 60 . 
Table 1. Comparison of concentrations of the toxic elements in Scirpus mucronatus for the two treatments of bacteria 5 and bacteria 60 versus control sample

\begin{tabular}{|c|c|c|c|c|c|c|c|}
\hline Elements & $\begin{array}{c}\text { One-way } \\
\text { ANOVA test } \\
\text { (p-value) }\end{array}$ & \multicolumn{2}{|c|}{ Control } & \multicolumn{2}{|c|}{ Bacteria 5} & \multicolumn{2}{|c|}{ Bacteria 60} \\
\hline As & 0.945 & $0.12 \pm 0.03$ & $0.10-0.20$ & $0.11 \pm 0.01$ & $0.10-0.14$ & $0.12 \pm 0.04$ & $0.10-0.23$ \\
\hline $\mathrm{Cd}$ & 0.670 & $0.10 \pm 0.00$ & $0.10-0.11$ & $0.10 \pm 0.00$ & $0.10-0.10$ & $0.10 \pm 0.00$ & $0.10-0.10$ \\
\hline $\mathrm{Cu}$ & 0.178 & $0.07 \pm 0.01$ & $0.06-0.08$ & $0.07 \pm 0.00$ & $0.07-0.08$ & $0.07 \pm 0.01$ & $0.06-0.09$ \\
\hline $\mathrm{Mn}$ & 0.816 & $0.95 \pm 0.90$ & $0.15-2.84$ & $1.19 \pm 1.04$ & $0.25-3.36$ & $1.09 \pm 1.13$ & $0.14-3.89$ \\
\hline $\mathrm{Pb}$ & 0.677 & $0.18 \pm 0.14$ & $0.08-0.46$ & $0.22 \pm 0.21$ & $0.08-0.66$ & $0.19 \pm 0.15$ & $0.09-0.48$ \\
\hline $\mathrm{Sb}$ & 0.091 & $0.12 \pm 0.00$ & $0.11-0.13$ & $0.12 \pm 0.00$ & $0.11-0.12$ & $0.12 \pm 0.00$ & $0.12-0.12$ \\
\hline $\mathrm{Se}$ & 0.291 & $0.05 \pm 0.00$ & $0.05-0.06$ & $0.06 \pm 0.00$ & $0.05-0.06$ & $0.05 \pm 0.00$ & $0.05-0.06$ \\
\hline $\mathrm{Zn}$ & 0.519 & $0.16 \pm 0.03$ & $0.13-0.21$ & $0.17 \pm 0.02$ & $0.14-0.21$ & $0.16 \pm 0.03$ & $0.14-0.21$ \\
\hline
\end{tabular}

SD: standard deviation
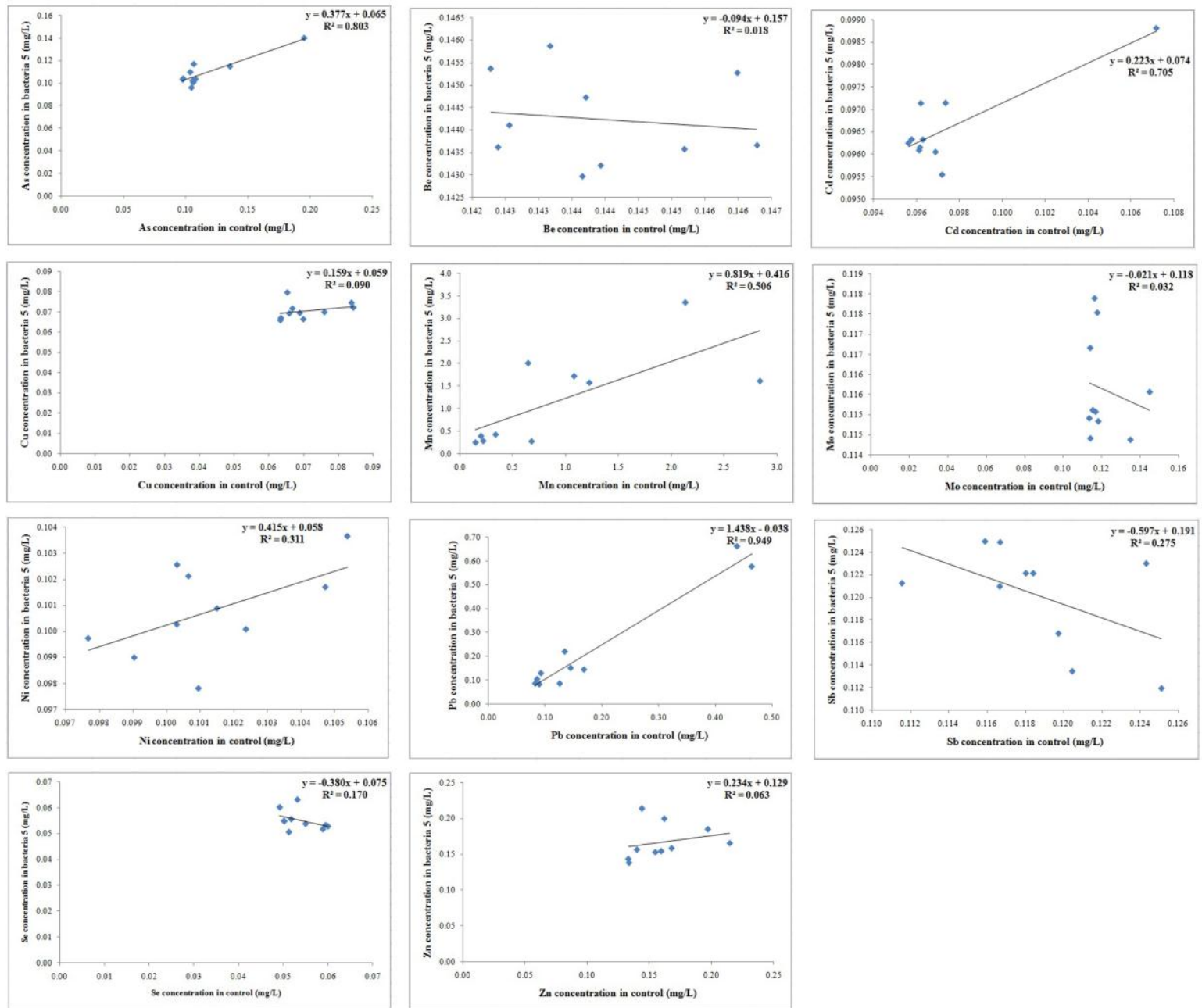

Fig 12. Relationship between $\mathrm{As}, \mathrm{Be}, \mathrm{Cd}, \mathrm{Cu}, \mathrm{Mn}, \mathrm{Mo}, \mathrm{Ni}, \mathrm{Pb}, \mathrm{Sb}, \mathrm{Se}$, and $\mathrm{Zn}$ concentrations in bacteria 5 sample versus control sample. R: Pearson's correlation cofficient 

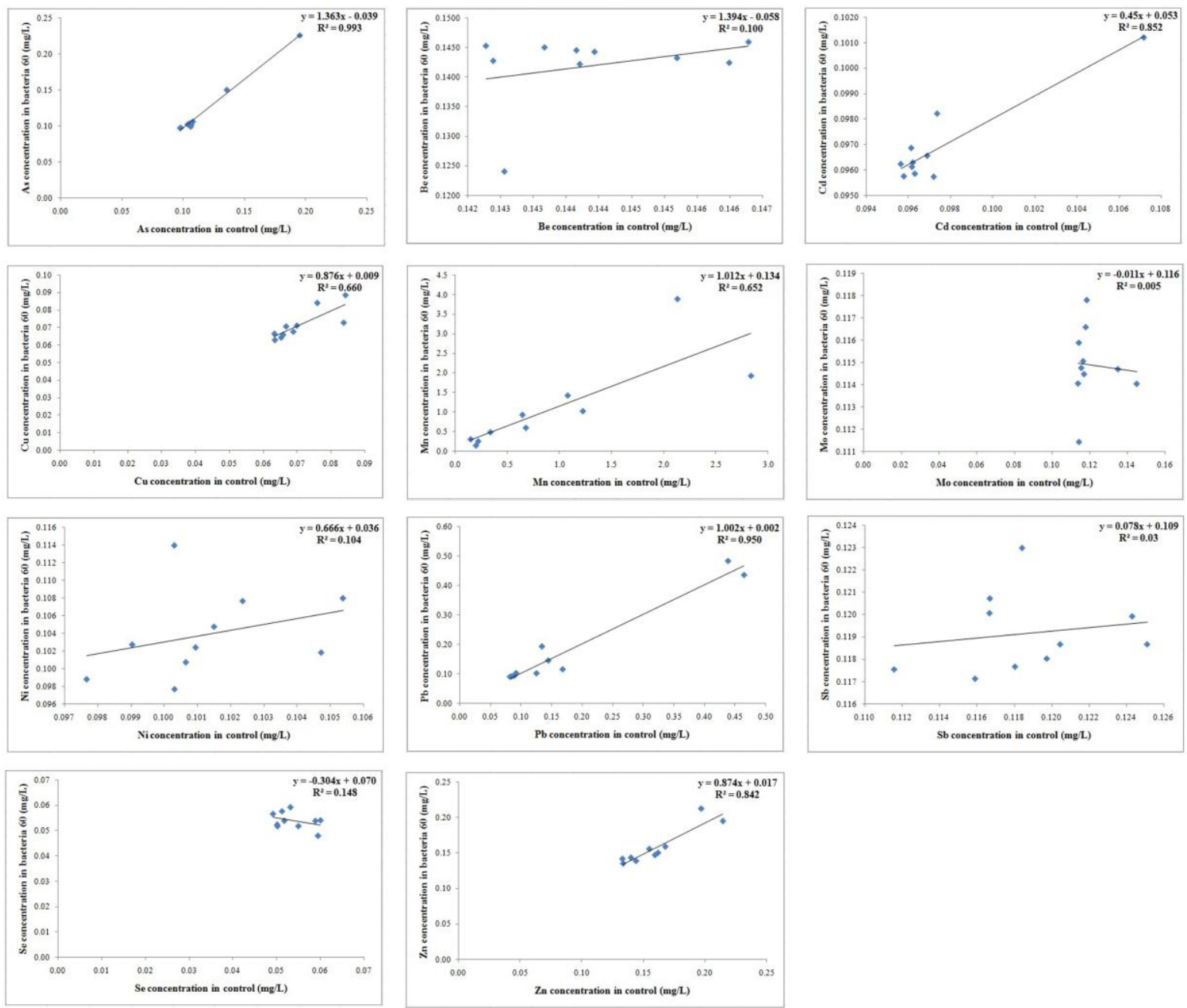

Fig 13. Relationships between $\mathrm{As}, \mathrm{Be}, \mathrm{Cd}, \mathrm{Cu}, \mathrm{Mn}, \mathrm{Mo}, \mathrm{Ni}, \mathrm{Pb}, \mathrm{Sb}, \mathrm{Se}$, and $\mathrm{Zn}$ concentrations in bacteria 60 sample versus control sample. $\mathrm{R}$ : Pearson's correlation cofficient

The tolerance and accumulation of metal vary from plant to plant and also from species to species within a genus [16]. Therefore, the obtained results of this study may be useful as database on properties phytoremediation of plant Scirpus mucronatus.

\section{CONCLUSION}

This study investigated the effectiveness of two bacterium, Brevundimonas diminuta and Alcaligenes faecalis, for heavy metal uptake by the plant Scirpus mucronatus growing in lead-contaminated soil. The results showed that the toxic elements (As, $\mathrm{Be}, \mathrm{Cd}, \mathrm{Cu}, \mathrm{Mn}, \mathrm{Mo}, \mathrm{Ni}, \mathrm{Pb}, \mathrm{Sb}, \mathrm{Se}$, and $\mathrm{Zn}$ ) were transported from the soil to the plant and that the concentrations of the elements in the plant tissues were higher in the samples inoculated with bacterium than in the un-inoculated control. The concentrations of the elements for all of the treatments were also higher after 42 days than after 1 day, particularly for $\mathrm{Mn}$, and $\mathrm{Pb}$. The statistical differences of our results were determined by one-way ANOVA test. P-values determined by one-way ANOVA test were demonstrated which there were significant statistical differences in all elemental concentrations between samples of bacteria 5, bacteria 60 and control $(\mathrm{p}>0.05)$. Pearson's correlation test was used to find the correlation between trace element levels in bacteria 5 and bacteria 60 versus control sample. In the present study, There were significant correlations between the all elements $(\mathrm{R}>0.3)$ except Be, Mo and $\mathrm{Zn}$ in sample of bacteria 5 versus control; as well $\mathrm{Sb}$ in sample of bacteria 60 . This finding indicates the products of the bacterial growth could mobilize these toxic metals in the contaminated soil. As well, the obtained results of this study may be useful as database on properties phytoremediation of plant Scirpus mucronatus. 


\section{Acknowledgments}

We thank the personnel of the ICP-OES lab in School of Biosciences and Biotechnology, as well UKM for their participations. This work was also partly supported by project funding of FRGS/1/2013/SG02/UKM/02/2.

\section{REFERENCES}

[1] A.C. Adriano, Trace elements in terrestrial environments and risk of metals. Chapter 18 (selenium). Springer, 2nd ed., 2001, 866868.

[2] P. Sharma, and R.S. Dubey, Lead Toxicity in Plant. Brazilian Journal of Plant Physiology. 17(1), 2005, 35-52.

[3] U.S. Environmental Protection Agency. Soil screening guidance: User's guidance. USEPA 540/R-96/018. USEPA, Washington, DC. 1996.

[4] P. Agamuthu, OP. Abioye, and AA. Aziz, Phytoremediation of soil contaminated with used lubricating oil using Jatrophacurcas. Journal of Hazardous Materials. 179(1-3), 2010, 891-894.

[5] D. Baldantoni, R. Ligrone, and A. Alfani, Macro-and trace- element concentrations in leaves and roots of Phragmitesaustralis in a volcanic lake in Southern Italy. Journal of Geochemical Exploration. 101, 2009, 166-174.

[6] G. Adam, and H. Duncan, Influence of diesel on seed germination. Environmental pollution, 120, 2002, 363-370.

[7] I. Alkorta, J. Hernandez-Allica, JM. Becerril, I. Amezaga, I. Albizu, and C. Garbisu, Recent Findings on the Phytoremediation of Soils Contaminated with Environmentally Toxic Heavy Metals and Metalloids Such as Zinc, Cadmium, Lead, and Arsenic. Reviews in Environmental Science and Biotechnology, 3(1), 2004, 71-90.

[8] M.S. Khan, A. Zaidi, P.A. Wani, and M. Oves, Role of Plant Growth Promoting Rhizobacteria in the Remediation of Metal Contaminated Soils: A Review. Organic Farming, Pest Control and Remediation of Soil Pollutants Sustainable Agriculture Reviews, 1, 2010, 319-350.

[9] RA. Abou-Shanab, K. Ghanem, N. Ghanem, and A. Al-Kolaibe, The role of bacteria on heavy-metal extraction and uptake by plants growing on multi-metal-contaminated soils. World Journal of Microbiology and Biotechnology, 24(2), 2008, $253-262$.

[10] O. Babalola, Beneficial bacteria of agricultural importance. Biotechnology Letters, 32(11), 2010, 1559-1570.

[11] D.W. Nordstokke, B.D. Zumbo, S.L. Cairns, and.H. Saklofske, The operating characteristics of the nonparametric Levene test for equal variances with assessment and evaluation data. Practical Assessment, Research \& Evaluation, 16(5), $2011,1-8$.

[12] K. Shah, and J.M. Nongkynrih, Metal hyperaccumulation and bioremediation. Biologia Plantarum Journal. 51(4), 2007, 618634.

[13] R.B. Meagher, Phytoremediation of toxic elemental and organic pollutants. Current Opinion in Plant Biology, 3, 2000, $153-162$.

[14] P. Beckett, and R. Davis, The additively of toxic effects of copper, nickel, and zinc in young barely. New Phytologist Journal. 8, $1978,155-173$

[15] J.R. Peralta-Videa, J.L. Gardea-Torresdey, J. Walton, W.P. Mackay, and M. Duarte-Gardea, Effect of Zinc upon Tolerance and Heavy Metal Uptake in Alfalfa Plants (Medicago sativa). Bulletin of Environmental Contamination and Toxicology journal. 70, 2003, 1036-1044.

[16] O.V. Singh, S. Labana, G. Pandey, R. Budhiraja, and R.K. Jain, Phytoremediation: an overview of metallic ion decontamination from soil. Applied Microbiology and Biotechnology Journal. 61, 2003, 405-412. 